\title{
Pelatihan Penggunaan Teknologi untuk Pengajaran Bahasa Inggris secara Inovatif Di Kelas untuk Guru-Guru MGMP Bahasa Inggris di Kabupaten Bantul
}

\author{
Training on the Use of Technology for Innovative Teaching in English Classes for MGMP \\ Teachers in Bantul District
}

Daniel Ari Widhiatama
Dangin*
Department of English language
education, Universitas Mercu Buana
Yogyakarta, Bantul, Special Region of
Yogyakarta, Indonesia
email: dangin@mercubuana-
yogya.ac.id
Kata Kunci
CALL
MALL
Pengajaran dan pembelajaran
Teknologi pendidikan
Keywords:
CALL
MALL
Teaching and learning
Education technology
Received: December 2020
Accepted: May 2021
Published: June 2021

\begin{abstract}
Abstrak
Penerapan teknologi berbasis CALL (Computer Assisted Language Learning) dan MALL (Mobile Asssisted Language Learning) di dalam pembelajaran bahasa di kelas bukan merupakan hal baru lagi di era ini. Bermacammacam aplikasi tersedia secara gratis di internet. Akan tetapi, pengetahuan guru-guru di Indonesia tentang fungsi dan cara penerapan aplikasi-aplikasi tersebut masih tergolong rendah. Dengan adanya pelatihan ini maka diharapkan guru-guru semakin mampu menggunakan aplikasi berbasis CALL dan MALL dan menjelaskan sisi pedagogisnya secara bersamaan.
\end{abstract}

\begin{abstract}
The application of CALL (Computer Assisted Language Learning) and MALL (Mobile Assisted Language Learning) based technology in language learning in the classroom is not new in this era. A variety of applications are available for free on the internet. However, the knowledge of teachers in Indonesia about the functions and ways of implementing these applications is still low. With this training, it is hoped that teachers will be increasingly able to use CALL and MALL-based applications and explain the pedagogical side simultaneously.
\end{abstract}

(C) 2021 Daniel Ari Widhiatama, Dangin. Published by Institute for Research and Community Services Universitas Muhammadiyah Palangkaraya. This is Open Access article under the CC-BY-SA License (http://creativecommons.org/licenses/by-sa/4.0/). DOI: https:// doi.org/10.33084/pengabdianmu.v6i4.1877

\section{PENDAHULUAN}

Saat ini, penerapan teknologi informasi dan komputer (TIK) begitu menjadi pusat perhatian karena dengan mengintegrasikan TIK ke dalam pembelajaran maka akan didapatkan beberapa keuntungan. Penerapan TIK di kelas dapat menciptakan iklim belajar yang efektif dan dapat membantu siswa yang memiliki pemahaman lamban. Selain itu TIK juga dapat merangsang siswa untuk mengerjakan latihan karena tersedianya animasi grafis, warna dan musik. Terakhir, kendali berada pada siswa sehingga kecepatan belajar dapat disesuaikan dengan tingkat kemampuan (Dewi \& Hilman, 2018).

Penggunaan luas berbagai teknologi digital bersama dengan bentuk materi pembelajaran lain yang sesuai telah menciptakan lingkungan pembelajaran online yang interaktif, berpusat pada peserta didik, terbuka dan fleksibel. Hal in juga berpotensi meningkatkan kualitas pembelajaran dengan bermacam aktifitas dan sumber pembelajaran (Andriani, 2015). Kegunaan pembelajaran 
online sebagai mode pengajaran dan pembelajaran yang efektif tidak hanya menarik perhatian para pendidik dan praktisi, tetapi juga diyakini mampu memperluas pandangan mereka tentang bagaimana menciptakan lingkungan belajar yang berorientasi pada siswa dan terbuka. Dalam hal ini, pendekatan yang tepat digunakan adalah student-centered (Suwarjo et al., 2012). Pendekatan ini lebih efektif jika dibandingkan pendekatan tradisional yang berorientasi pada pengajar semata dan menyebabkan siswa menjadi pasif. Meski demikian, tak serta merta penggunaan teknologi dalam pengajaran dapat dilakukan secara lepas. Dalam hal ini, pengajar tidak disarankan membiarkan siswa menggunakan teknologi tanpa adanya bimbingan dan metode yang sesuai (Nurrita, 2018). Penggunaan teknologi yang tidak diikuti oleh kemampuan guru dalam menguasai teknologi (untuk mengajar dan membimbing) akan mengakibatkan menurunnya motivasi siswa dalam belajar. Hal ini disebabkan bahwasanya, siswa tetap membutuhkan intruksi yang komprehensif dari guru sebagai instruktur (Arianti, 2018).

Selanjutnya, dalam perihal pengajaran, kemajuan teknologi juga menjadi perhatian Pathak dan Manoj (2018). Dalam studinya, mereka menemukan bukti saintifik bahwa teknologi mampu menstimulasi proses pembeajaran bagi siswa. Dalam hal praktisi, mereka juga menemukan bahwa pengajar atau user dari teknologi merasa dimudahkan dan terpacu untuk membuatkreasi-kreasi baru dalam pengajaran.

Guru diharapkan mampu menyediakan materi yang dapat dengan fleksibel diakses oleh siswa. Selanjutnya, guru juga diharapkan mampu secara komprehensif memberi tanggapan dan penilaian terhadap kinerja siswa. Pentingnya corrective feedback juga ditekankan oleh Wong dan Yang (2017) serta Strimel dan Grubbs (2016). Di dalam pembelajaran bahasa, TIK juga berperan penting baik bagi guru maupun bagi siswa. TIK sendiri dapat dikategorikan menjadi beberapa segmen, antara lain CALL (Computer Assisted Language Learning) atau pembelajaran bahasa dengan bantuan computer dan MALL (Mobile Assisted Language Learning) atau pembelajaran bahasa dengan bantuan ponsel. Bagi guru, peran CALL dan MALL cukup membantu terlebih di dalam mewujudkan pengajaran yang efektif dan pembelajaran yang berarti yang mengacu pada 5Cs (Communication, Collaboration, Critical Thinking, Creativity, and Charaters). Hal ini dipandang sangat penting karen teknologi akan memperluas dan mempersemoit keterbatasan guru dan siswa dalam mengakses materi (Stošić, 2015).

Menimbang dari kondisi di atas, dirasa perlu dengan adanya pelatihan untuk guru-guru untuk mendalami lebih tentang penggunaan teknologi berbasis CALL dan MALL demi terciptanya mutu kualitas pengajaran dan pembelajaran bahasa Inggris di kelas. Menanggapi fenomena tersebut, dalam program ini, guru juga akan diberi pengarahan dan pemahaman mendalam tentang tren teknologi yang dapat digunakan sebagai basis dari pengajaran.

\section{METODOLOGI}

Pelaksanaan pelatihan akan dilaksanakan di Dispora Bantul. Peserta dari pelatihan adalah guru-guru yang mengampu mata pelajaran bahasa Inggris di Kabupaten Bantul. Untuk pertemuan, pelatihan ini ditargetkan akan diselenggarakan dalam 2 peretemuan atau selama 2 hari dengan 2 materi yang berbeda.

Metode yang akan digunakan dalam pelatihan ini adalah pendekatan pada praktium karena luaran yang ditargetkan adalah dosen atau perserta pelatihan mampu memahami dan mempraktikan materi yang diberikan 
Untuk hari pertama, guru-guru dikenalkan dengan konsep SAMR dan seamless learning. Kemudian, guruguru akan dikenalkan dengan model pembelajaran berbasis 5 Cs. Selanjutnya, para guru akan mendapatkan materi seputar cara penggunaan aplikasi Edpuzzle untuk pembelajaran bahasa. Tujuan dari aplikasi ini adalah untuk menciptakan pembelajaran yang lebih mengasah kolaborasi dan pemikiran kritis. Di hari kedua, guruguru akan difokuskan untuk mempelajari aplikasi berbasis ponsel. Aplikasi yang akan dipakai adalah Edpuzzle. Tujuan dari aplikasi ini adalah untuk menciptakan kelas berbicara yang lebih interaktif.

Hal ini sangatlah penting dikarenakan dalam analisa atau observasi yang dilakukan, guru banyak mendapati kesulitan dalam pengadaan kuis secara online. Mereka mengalami kesulitan tentang bagaimana membuat kuis tersebut, apa waah dari kuis online tersebut karena ini berkaitan dengan skill listening dan bagaimana membuat penilaian tentang tugas atau kuis yang diberikan. Langkah pertama yang kami lakukan adalah memperkenalkan website Edpuzzle. Guru diberi pengertian dan gambaran tentang fitur dari aplikasi website tersebut.



Gambar 1. Proses pelatihan penggunaan aplikasi Edpuzzle kepada peserta workshop

Selanjutnya, setelah proses pengenalan dilaksanakan, para peserta mendapatkan kesempatan untuk mempratikan materi yang telah diberikan. Mereka di bagi menjadi beberapa group dan mendapatkan peran sebagai guru yang menydiakan materi dan siswa yang mengerjakan kuis.
Masih di hariyang sama, para peserta juga mendapatkan materi tentang Students Response System. Tujuan pengenalan aplikasi ini adalah mempermudah guru melakukan evaluasi dan refleksi setelah proses pembelajaran dilaksanakan. Aplikasi ini juga digunakan untuk mendapatkan indikator tentang pencapaian dan permasalah siswa dalam proses pembelajaran.

Aplikasi yang diperkenalkan adalah Mentimeter. Aplikasi ini memungkinan guru melakukan survey secara realtime dan online. Dari hasil survey, guru akan mendapati hasil-hasil tentang saran maupun hambatan yang dihadapi siswa. Dalam proses pelatihan, guru diperkenalkan tentang nama aplikasi dan fitur yang ada didalamnya. Metode perkenalan terlebih dahulu ditujukan agar guru mempunyai gambaran tentang aplikasi yang dipelajari. Selanjutnya, tim melakukan workshop tentang cara penggunaan baik dalam menyusun konten hingga menerjemahkan hasil dari survey.

Pada hari kedua, pelatihan dilaksanakan dengan metode yang sama dengan hari pertama. Namun, materi hari kedua mendapatkan alokasi waktu lebih dikarenakan tingkat kerumitan dan kompleksitas materi yang lebih tinggi. Materi tersebut adalah Learning Management System (LMS). Terdapat banyak LMS yang tersedia secara gratis di internet, tetapi tim pengabdian UMBY mencoba menyuguhkan LMS yang paling sederhana dan lebih mudah untuk dipelajari dan diaplikasikan.

Para peserta pelatihan mendapat Google Classroom sebagai bahan pelatihan. Seperti hari sebelumnya, metode yang digunakan adalah pengenalan dan praktikum. Pada tahap pertama, peserta akan diperkenalkan tentang gambaran umum dari Google Classroom mulai dari fitur hingga fungsi dari LMS tersebut. Bagi sebagian guru, LMS ini adalah LMS yag baru pertama kali mereka gunakan atau pertama kali mempelajarinya. Hal ini dikarenakan mereka mendapati 
kesulitan jika diharuskan mempelajari materi secara mandiri. Sebelumnya, guru lebih nyaman dan merasa mampu mengadakan proses pembelajaran dengan menggunakan WhatsApp group.

\section{HASIL DAN PEMBAHASAN}

Setelah dilaksanakannya program pelatihan penggunaan teknologi kepada guru bahasa inggris tingkat SMP se-kabupaten Bantul, kemudian didapat hasil yang telah dicapai dilihat dari beberapa aspek sebagai berikut.

\section{Aspek perspektifguru tentang penggunaan teknologi}

Dalam aspek ini, didapati bahwa sebelum bergabung dengan program pelatihan penggunaan teknologi dalam proses pembelajaran guru cenderung menganggap bahwa teknologi adalah hal yang kompleks dan mereka merasa berat dalam mempelajarinya. Menanggapi hal tersebut, tim pengabdian UMBY berupaya meningkatkan motivasi guru dalam hal ini tentang perspektif mereka terhadap penggunaan teknologi. Hasilnya, setelah kami mencoba melakukan pendekatan dan sosialisasi tentang aplikasi yang dapat digunakan, guru merasa bahwa teknologi sangat bermanfaat dan dapat mempermudah mereka dalam proses pembelajaran. Budhwar (2017) mengungkapkan bahhwa perspektif guru tentang penggunaan teknologi di dalam kelas sangatlah penting karena mereka memiliki peran yang vital di dalam proses pembelajaran.

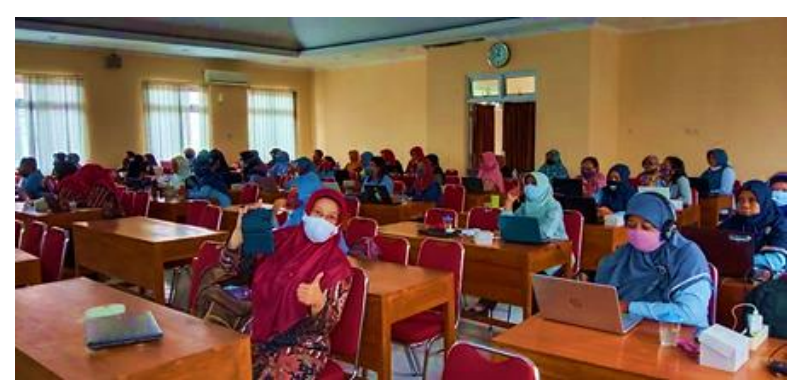

Gambar 2. Antusiasme peserta pelatihan dalam mempelajari penggunaan teknolgi di dalam kelas

\section{Aspek Pengetahuan}

Pada aspek ini, kami selaku tim pengabdian UMBY bertujuan untuk menambah wawasan tentang penggunaan teknologi dalam proses pemeblajaran dan landasan teori yang bisa dijadikan acuan penggunaannya. Seperti yang disampaikan sebelumnya, kami menggunakan pendekatan yang memungkinkan peserta dapat menyentuh teknologi secara langsung dan memahami fitur didalam program pelatihan. Sebagai hasilnya, para peserta merasa mendapatkan pengetahuan tentang hal-hal baru yang berkaitan dengan penggunaan berbagai teknologi di dalam kelas.

\section{Aspek kemampuan}

Aspek ini menjadi aspek inti atau tujuan utama dalam program pelatihan. Peserta diharapkan mampu mengoperasikan beberapa website atau aplikasi yang disajikan dalam program pelatihan. Pertama kami menggunakan metode scaffolding untuk menumbuhkan rasa percaya diri peserta bahwa mereka mampu menggunakan aplikasi tersebut. Setalah langkah scaffolding terlaksana, kami memberi kesempatan kepada peserta untuk mempraktikan penggunaan aplikasi secara mandiri. Hasilnya, mayoritas dari peserta mampu secara mandiri menggunakan teknologi yang kami paparkan dengan baik dan benar. Mahini et al. (2012) dan Cloete (2017) menemukan bahwa kemampuan pengajar dalam mengaplikasikan teknologi didalam kelas akan membantu mereka sebagai seorang guru dalam mengajar dan siswa dalam menerima materi pembelajaran. Dari hal tersebut dapat ditarik kesimpulan bahwa program pengabdian kepada masyarakat ini mampu membantu para guru mengasah dan meningkatkan kemampuan mereka dalam penggunaan teknologi di dalam kelas. 


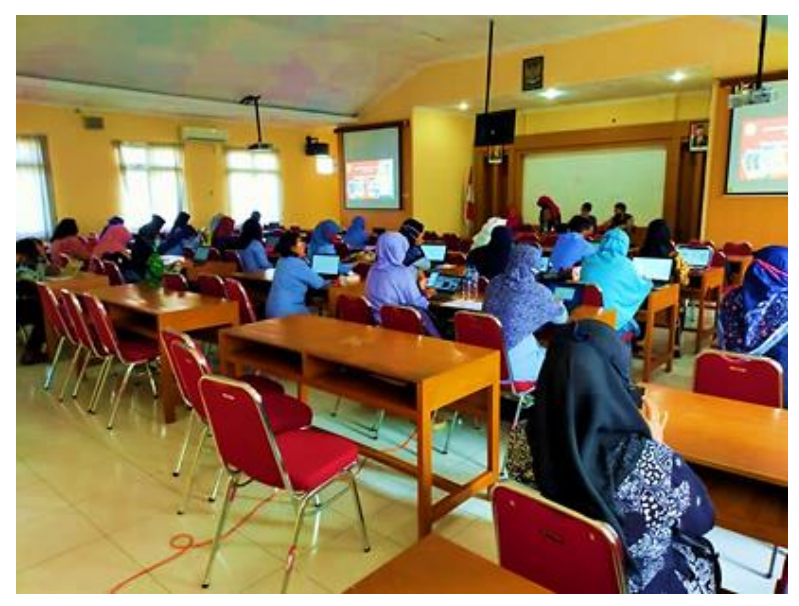

Gambar 3. Para peserta sedang melakukan pratikum mandiri tentang menejemen Google Classroom

\section{KESIMPULAN}

Dari pembahasan diatas, dapat kita simpulkan bahwa guru harus mendapatkan lebih banyak eksposur tentang perihal berkaitan dengan teknologi. Dari hasil survey yg dilakukan sebelum kegiatan pelatihan ini dimulai, banyak guru beranggapan bahwa mereka sudah tidak mampu atau merasa sangat sulit untuk mengikuti penerapan teknologi didalam kelas. Akan tetapi, setelah mengikuti pelatihan, guru merasa teknologi sangat membantu didalam proses pembelajaran. Oleh karena itu, dapat disimpulkan bahwa penggunaan teknologi didalam proses pembelajaran akan sangat mambantu ketika guru mampu menguasai an menggunakan teknologi dalam proses pembelajaran.

\section{UCAPAN TERIMA KASIH}

Pertama kali kami ucapkan terima kasih kepada MGMP SMP Bahasa Inggris Kabupaten Bantul yang bereknan bekerjasama hingga terlaksananya program pelatihan ini. Yang kedua kami ucapkan terimakasih kepada P3MK UMBY yang telah mendukung kamis dari proses penentuan mitra, pembuatan proposal hingga publikasi dari program pelatihan ini.

\section{REFERENSI}

Andriani, T. 2015. Sistem Pembelajaran Berbasis Teknologi Informasi Dan Komunikasi. Sosial Budaya. 12(1):127-150. http:/ /dx.doi.org/10.24014/sb.v12i1.1930

Arianti, A. 2018. Peranan Guru Dalam Meningkatkan Motivasi Belajar Siswa. Didaktika: Jurnal Kependidikan. 12(2):117-134. http:/ /dx.doi.org/10.30863/didaktika.v12i2.1 81

Budhwar, K. 2017. The Role of Technology in Education. International Journal of Engineering Applied Sciences and Technology. 2(8):55-57.

Cloete, A.L. 2017. Technology and education: Challenges and opportunities. HTS Teologiese Studies. 73(4): a4589.

http:/ /dx.doi.org/10.4102/hts.v73i4.4589

Dewi, S.Z., Hilman, I. 2018. Penggunaan TIK Sebagai Sumber Dan Media Pembelajaran Inovatif Di Sekolah Dasar. Indonesian Journal of Primary Education. 2(2):48-53. https://doi.org/10.17509/ijpe.v2i2.15100

Mahini, F., Forushan, Z.J.A., Haghani, F. 2012. The Importance of Teacher's Role in TechnologyBased Education. Procedia - Social and Behavioral Sciences. 46:1614-1618. https://doi.org/10.1016/j.sbspro.2012.05.348

Nurrita, T. 2018. Pengembangan Media Pembelajaran Untuk Meningkatkan Hasil Belajar Siswa. Misykat: Jurnal Ilmu-ilmu Al-Qur'an, Hadist, Syariah dan Tarbiyah. 3(1):171-187. http://dx.doi.org/10.33511/misykat.v3n1.17 1

Pathak, K., Manoj, N.K. 2018. ICT in Educational Institution: Need, Role and Importance. IOSR Journal of Humanities and Social Science. 23(1):4246. http:/ / doi.org/10.9790/0837-2301084246

Stošić, L. 2015. The Importance of Educational Technology in Teaching. International Journal of Cognitive Research in Science, Engineering and Education. 3(1):111-114. https://doi.org/10.23947/2334-8496-2015-3$1-111-114$

Strimel, G.J., Grubbs, M. 2016. Positioning Technology and Engineering Education as a Key Force in STEM Education. Journal of Technology 
Education. 21-36.

https://doi.org/10.21061/jte.v27i2.a.2

Suwarjo, S., Maryatun, I.B., Kusumadewi, N. 2012. Penerapan Student Centered Approach pada Pembelajaran Taman Kanak-Kanak Kelompok B (Studi Kasus di Sekolah Laboratorium Rumah Citta). Jurnal Pendidikan Anak. 1(1):79-102. https://doi.org/10.21831/jpa.v1i1.2924

Wong, G., Yang, M. 2017. Using ICT to Facilitate Instant and Asynchronous Feedback for Students' Learning Engagement and Improvements. In Emerging Practices in Scholarship of Learning and Teaching in a Digital Era. Singapore: Springer Nature. http://dx.doi.org/10.1007/978-98110-3344-5_18 